\title{
PELATIHAN TERAPI AIR TERHADAP KONSTIPASI MASA KEHAMILAN PADA BIDAN DI PUSKESMAS LANGSA BARAT KOTA LANGSA
}

DOI: https://doi.org/10.33024/jkpm.v4i4.3919

\author{
Henniwati ${ }^{1 *}$, Dewita ${ }^{2}$ \\ 1,2Prodi DIII Kebidanan Langsa Poltekkes Kemenkes Aceh \\ Disubmit: 26 Februari 2021 Diterima: 05 Mei $2021 \quad$ Diterbitkan: 02 Agustus 2021 \\ Email Korespondensi: henniwati976@yahoo.com
}

\begin{abstract}
ABSTRAK
Tenaga kesehatan khusunya bidan sanggat penting untuk meningkatkan pengetahuan dan keterampilan. Untuk meningkatkan itu semua diperlukannya pelatihan-pelatihan khususnya kebidanan. Pelatihan merupakan suatu proses dimana seseorang mencapai kemampuan tertentu. Konstipasi yang sering terjadi selama kehamilan yaitu konstipasi. Prevalensi sembelit pada kehamilan berkisar antara $11 \%$ sampai $44 \%$. Salah satu terapi untuk mengatasi konstipasi adalah dengan terapi air. Tujuan kegiatan ini untuk menambah pengalaman, pengetahuan dan kompetensi dalam pemberian asuhan kebidanan terhadap mengurangi konstipasi pada ibu hamil. Pelatihan diberikan selama 3 hari kepada bidan desa, diberikan selama 2 jam. Pengetahuan dan keterampilan bidan menjadi lebih baik setelah mendapatkan edukasi da pelatihan tentang terapi air terhadap konstipasi pada ibu hamil.
\end{abstract}

Kata Kunci : Pelatihan, Terapi Air, Konstipasi

\section{ABSTRACT}

Health workers, especially midwives, it is very important to increase knowledge and skills. To improve it all requires training, especially midwifery. Training is a process by which a person reaches certain abilities. Constipation that often occurs during pregnancy is constipation. The prevalence of constipation in pregnancy ranges from $11 \%$ to $44 \%$. One of the therapies to treat constipation is water therapy. The purpose of this activity is to increase experience, knowledge and competence in providing midwifery care to reduce constipation in pregnant women. Training is given for 3 days to village midwives, given for 2 hours. The knowledge and skills of midwives became better after receiving education and training on water therapy for constipation in pregnant women.

Keywords: Training, Water Therapy, Constipation 


\section{PENDAHULUAN}

Ketidaknyamanan yang sering terjadi pada trimester III pada masa kehamilan salah satunya adalah konstipasi. Konstipasi atau sembelit merupakan keadaan dimana sekresi dari sisa metabolism tubuh dalam bentuk fases menjadi keras sehingga menimbulkan kesulitan dalam defekasi (Solistiowati, 2016).

Angka kejadian konstipasi pada ibu hamil bekisar antara $11 \%-38 \%$, hal ini disebabkan oleh penurunan peristaltic usus akibat dari peningkatan hormon progesteron (Mirghafourvand, 2016). Konstipasi merupakan gejala yang sering terjadi pada masa kehamilan. Ini dikarenakan efek dari kadar hormone yang berubah pada saluran pencernaan. Penyebab lain dari konstipasi yaitu suplementasi vitamin dan zat besi serta kurangnya asupan cairan. Pada umunya wanita yang mengalami konstipasi sebelum hamil akan memperburuk ketika wanita tersebut dalam kondisi hamil (Rungsiprakarn, 2015)

Penelitian yang diteliti dari Departemen Kebidanan Universitas Lowa Amerika Serikat, menemukan bahwa sebanyak $25 \%$ ibu hamil menderita konstipasi atau sembelit akan berlanjut samapi 3 bulan setelah melahirkan, maka dari itu konstipasi merupakan hal yang serius, karena tidak hanyak mengganggu kehamilan tetapi juga beresiko pada kerusakan otot panggul (pelvic floor damage) (Hamidin, 2015).

Penanganan secara nonfarmakologi yang dapat diberikan kepada penderita konstipasi salah satunya adalah terapi air. Terapi air merupakan metode penyembuhan dengan menggunakan air untuk mendapatkan efek-efek terapis atau penyembuhan (Hamidin, 2015).

Penggunaan terapi air sangat mudah dan sederhana, efek samping dari terapi air ini merupakan tergolong minimal karena air merupakan komponen fisiologis yang senantiasa diperlukan oleh tubuh. Pemberian terapi air yang dimaksud dengan pemberian sebanyak 1,5 liter air putih (Nurin \& Anzhor, 2017).

Bagi seorang tenaga kesehatan khsusnya bidan sangat perlu untuk meningkatkan pengetahuan dan keterampilan seta kompentesi yang ada didirinya. Untuk meningkatkan itu semua maka salah satu yang diperlukan adalah dengan mengikuti pelatihan-pelatihan tentang kebidanan. Pelatihan merupakan suatu proses dimana orang-orang mencapai kemampuan tertentu untuk membantu mencapai tujuan organisasi. ecara terbatas, pelatihan menyediakan para pegawai dengan pengetahuan yang spesifik dan dapat diketahui serta keterampilan yang digunakan dalam pekerjaan mereka saat ini. Terkadang ada batasan yang ditarik antara pelatihan dengan pengembangan, dengan pengembangan yang bersifat lebih luas dalam cakupan serta memfokuskan pada individu untuk mencapai kemampuan baru yang berguna baik bagi pekerjaannya saat ini maupun di masa mendatang (Kusmiran, 2017).

Kegiatan pengabdian masyarakat ini merujuk pada penelitian yang telah dilakukan oleh Henniwati (2018) dengan judul menunjukkan Pengaruh Terapi Air Terhadap Konstipasi Pada Ibu Pasca Salin Sectio Caesarea di RSUD Langsa. Dimana hasil penelitian menunjukan bahwa ada pengaruh pemberian terapi 
air terhadap waktu defekasi pada ibu pasca salin SC. maka dapat disimpulkan ada pengaruh pemberian terapi air terhadap frekuensi defekasi pada ibu pasca salin SC.

Berdasarkan uraian diatas, untuk dapat menyelesaikan permasalahan yang ditimbulkan terhadap konstipasi setelah persalinan, sehingga dapat menjadi salah satu pemahaman, sikap dan prilaku terutama pada ibu hamil trimester III, penulis melakukan pelatihan kepada bidan bagaimana memberikan asuhan kepada ibu hamil dengan keluhan kostipasi, dengan pemberian terapi air untuk mengurangi konsipasi pada ibu hamil trimester III.

\section{MASALAH}

Alasan saya tempat intervensi dan demonstrasi terapi air untuk mencegah dan pengurangan konstipasi di Puskesmas Langsa Barat Kota Lagsa, karena banyak ibu hamil yang mengalami konstipasi dan serta para bidan belum mendapatkan informasi tentang terapi air. Tujuan umum yang diharapkan untuk menambah pengalaman, pengetahuan dan kompetensi dalam pemberian asuhan kebidanan terhadap mengurangi konstipasi pada ibu hamil. Tujuan khusus dalam kegiatan ini telah dilaksanakan pelatihan terapi air untuk pencegahan dan penanganan konstipasi pada ibu hamil, telah dilaksanakan analisis jurnal tentang pemberian terapi air untuk pengurangan konstipasi pada ibu hamil.

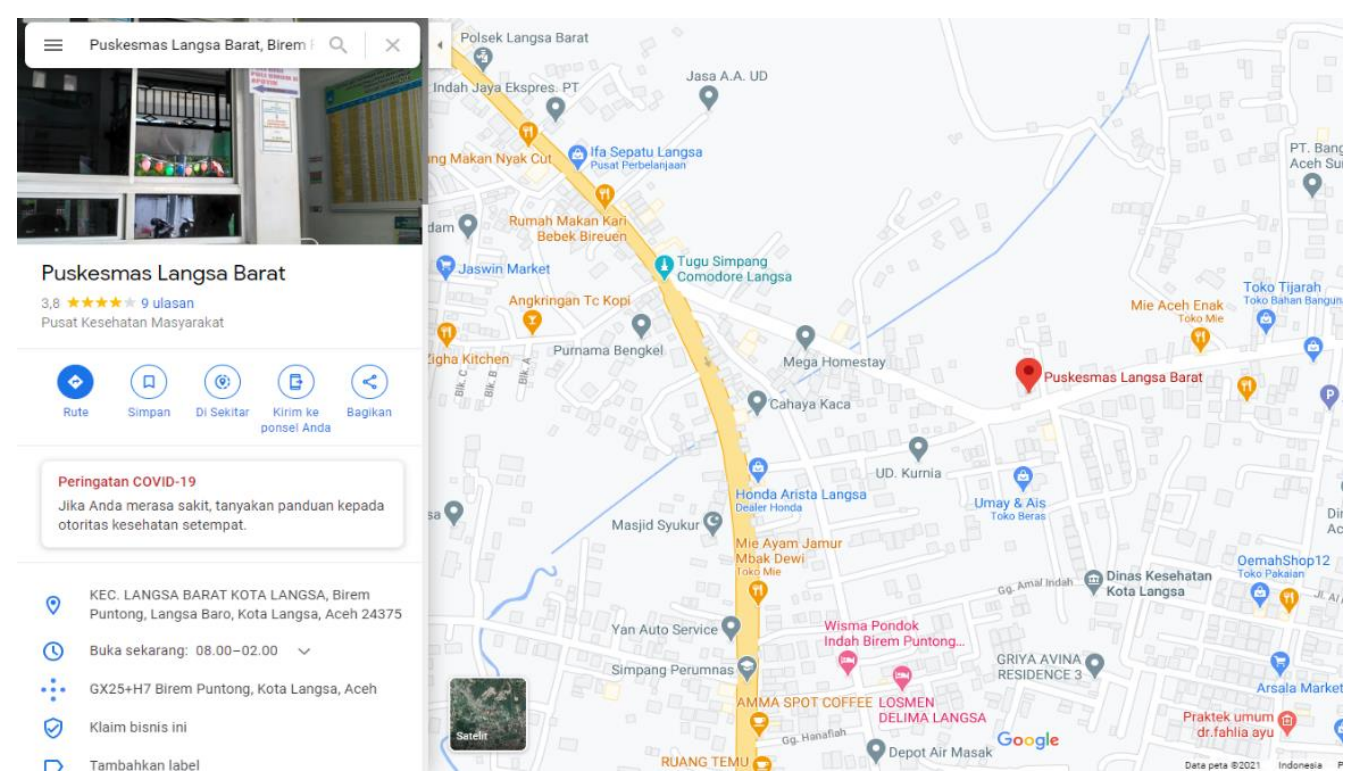

Gambar 1. Lokasi Sasaran di Puskesmas Langsa Barat Kota Langsa

\section{METODE}

a. Tujuan Persiapan

Tahapan persiapan dari kegiatan ini adalah yang pertama dilakukan peneliti survel lapangan, persiapan materi pelatihan, persiapan lokasi tempat pelatihan, persiapan bahan-bahan yang diperlukan pada saat pelatihan. 
b. Tahapan Pelaksanaan

Tahap pelaksanaan Pengabdian masyarakat dilakukan persiapan. Dalam tahap ini dilakukan pertama, penyebaran kuesioner untuk mengetahui pengetahuan bidan desa tentang terapi air terhadap konstipasi pada ibu hamil dan dengan memberikan penjelasan tentang kesehatan ibu hamil yang menitik beratkan pada penjelasan mengenai kelancaran konstipasi Kedua, melakukan pelatihan terapi air. Ketiga, evaluasi cara pemberian terapi air yang dilakukan bidan kepada ibu hamil dan sesi penyebaran kuesioner posttest setelah dilakukan penyuluhan dan pelatihan.

c. Evaluasi

a. Struktur

Sasaran sebanyak 13 orang bidan desa. Setting tempat sudah sesuai dengan rencana yang telah dibuat. Peran peneliti sesuai dengan tugasnya, baik sebagai penanggung jawab, observator, fasilitator dan dokumentasi. Penggunaan bahasa pada saat ketiatan pelatihan berlangsung sudah komunikatif dalam penyampaiaannya, sasaran dapat memahami apa yang telah disampaikan dan dapat mendemonstasikan kebali pelatihan yang telah diberikan

b. Proses

Pelaksaan pelatihan terapi air selama 3 hari, pada pukul $08.30 \mathrm{~s} / \mathrm{d} 10.30$. Sesuai jadwal yang direncanakan

\section{HASIL DAN PEMBAHASAN}

Kegiatan pengabdian kepada masyarakat ini dilaksanakan pada tanggal $07 \mathrm{~s} / \mathrm{d} 9$ oktober 2020 di Aula Puskesmas Langsa Barat Kota Langsa. Pelaksanaan pelatihan ditujukan kepada Bidan Desa Di wilayah Kerja Puskesmas Langsa Barat yang belum mengetahui terapi air untuk mencegah dan mengobati konstipasi pada ibu hamil Trimester III. Media dan alat yang digunakan yaitu LCD, leaflet, gelas dan air putih, metode yang digunakan ceramah dan tanyak jawab serta evaluasi dengan mempraktikan pemberian terapi air kepada ibu hamil. berikut gambar pelaksanaan kegiatan : 

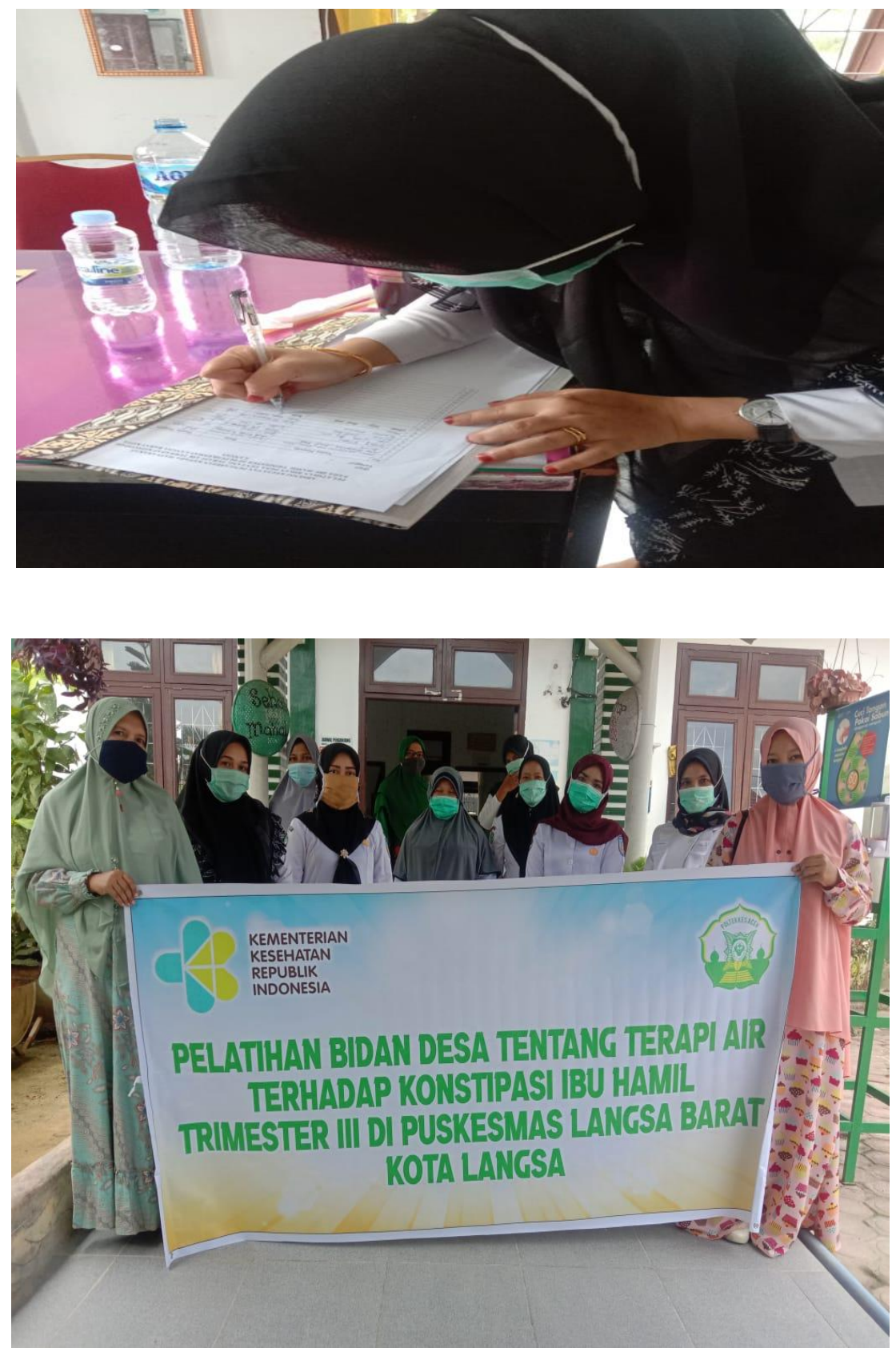

Gambar 2. Pelaksanaan Edukasi dan Pelatihan Terapi Air

\section{KESIMPULAN}

Konstipasi merupakan salah satu ketidaknyamanan selama kehamilan, hamper seluruh ibu hamil mengalami konstipasi.

pelatihan ini betujuan untuk meningkatkan pengetahuan dan keterampilan bidan dalam memberikan asuhan kebidanan yang komprehensif untuk mengurangi dan mencegah konstipasi pada ibu hamil dengan penggunaan terapi air, terapi ini tidak memiliki efeksamping dan murah. kegiatan pelatihan ini merupakan kegiatan yang positif dan dapat diterapkan pada saat memberikan asuhan kepada ibu hamil khususnya yang mengalami konstipasi. 


\section{DAFTAR PUSTAKA}

Hamidin A.S. (2015). Kebaikan Air Putih : Terapi Air Untuk Penyembuhan, Deit, Kehamilan dan kecantikan (edisi.2). Yogyakarta: Media Pressindo.

Henniwati. (2019). Pengaruh Penggunaan Terapi Air Terhadap Konstipasi Pada Ibu Pasca Salin Sectio Caesarea Di Rsud Langsa Tahun 2018. Jurnal AlMuntaz. Vo. 8 No. 1, Januari-Juni 2019. Hal78-86. https://jurnalalmumtaz.blogspot.com/2019/06/henniwati-jurnal-al-mumtaz-volume8.html

Kusmiran, E. (2018). Pelatihan Soft Skills Caring Meningkatkan Kualitas Pelayanan Keperawatan dan Kepuasan Pasien di Rumah Sakit Kota Bandung. Jurnal Penelitian Dan Pengembangan Pelayanan Kesehatan, 1(2), 72-81. https://doi.org/10.22435/jpppk.v1i2.440

Mirghafourvand M, Rad AH, Mohammad S, Charandabi A, Shokri K. (2016). The Effect of Probiotic Yogurt on Constipation in Pregnant Women: A Randomized Controlled Clinical Trial. Iranian Red Crescent Medical Journal. $\quad$ November;18(11):1-12 https://www.researchgate.net/publication/311355626_The_Effect_of_Pr obiotic_Yogurt_on_Constipation_in_Pregnant_Women_A_Randomized_Con trolled_Clinical_Trial

Nurin R. Karina., \& Anzhor Adhi S. (2017). Keajaiban Terapi Air Putih : Aman Tanpa Efek Samping. Jakarta ; Anak Hebat Indonesia.

Rungsiprakarn P, Laopaiboon M, Us S, Lumbiganon P, Jj P. (2015). Interventions for treating constipation in pregnancy (Review). Cochrane Data base of Systematic Reviews 2015, Issue 9.Art.No.:CD011448 (9). DOI: 10.1002/14651858.CD011448.pub2

Sulistiowati Yunita Dwi. (2016). Upaya Penanganan Konstipasi Pada Ibu Hamil Trimester III di Puskesmas Grogol Sukorejo. Naskah Publikasi IImiah Universitars Muhammadiyah Surakarta. http://eprints.ums.ac.id/44469/ 